Article

\title{
Analysis of Polymorphism rs1333049 (Located at 9P21.3) in the White Population of Western Siberia and Associations with Clinical and Biochemical Markers
}

\author{
Elena Shakhtshneider ${ }^{1,2}, * \mathbb{D}$, Pavel Orlov ${ }^{1,2}$, Sergey Semaev ${ }^{1,2}$, Dinara Ivanoshchuk ${ }^{1,2}$, \\ Sofia Malyutina ${ }^{1}$, Valery Gafarov ${ }^{1}$, Yuliya Ragino ${ }^{1}$ and Mikhail Voevoda ${ }^{1,2}$ \\ 1 Institute of Internal and Preventive Medicine-branch of Institute of Cytology and Genetics, Siberian Branch \\ of Russian Academy of Sciences (SB RAS), Bogatkova Str. 175/1, Novosibirsk 630004, Russia \\ 2 Federal research center Institute of Cytology and Genetics, SB RAS, Prospekt Lavrentyeva 10, \\ Novosibirsk 630090, Russia \\ * Correspondence: 2117409@mail.ru or shakhtshneyderev@bionet.nsc.ru; Tel./Fax: +7-(383)-264-2516
}

Received: 18 June 2019; Accepted: 17 July 2019; Published: 19 July 2019

\begin{abstract}
The 9p21.3 chromosomal region is a marker of the risk of cardiovascular diseases. The aim of this study was to analyze single-nucleotide polymorphism rs1333049 (chr9:22125504) in the population of Western Siberia (Russia) and possible associations with clinical and biochemical parameters. The population included in the analyses was selected from a sample surveyed within the framework of the Health, Alcohol and Psychosocial Factors In Eastern Europe (HAPIEE) study (9360 participants, $>90 \%$ white, aged 45-69, males: 50\%). In total, 2729 randomly selected patients were included. Plasma lipid levels were determined by standard enzymatic assays. Rs1333049 was analyzed by RT-PCR (BioLabMix, Russia). Frequencies of rs1333049 genotypes C/C (homozygote), $\mathrm{C} / \mathrm{G}$ (heterozygote), and $\mathrm{G} / \mathrm{G}$ were $0.22,0.51$, and 0.27 in this population. The Allele $\mathrm{G}$ frequency was 0.53 . We found an association of allele $\mathrm{G}$ with total cholesterol and low-density lipoprotein cholesterol levels among male participants ( $p=0.004$ and $p=0.002$, respectively). Allele $C$ was significantly associated with the risk of myocardial infarction among the male participants (odds ratio $1.96,95 \%$ confidence interval 1.14-3.38, $p=0.017$ ) and the study population (odds ratio $1.83,95 \%$ confidence interval 1.23-2.72, $p=0.004$ ). Thus, rs1333049 is associated with myocardial infarction in the white population of Western Siberia (Russia).
\end{abstract}

Keywords: rs1333049; risk of cardiovascular disease; lipid profile; white population; Western Siberia

\section{Introduction}

One of the markers of cardiovascular disease (CVD) risk is chromosomal region 9p21.3. It contains two genes (encoding proteins CDKN2A and CDKN2B) and the gene of long noncoding RNA ANRIL (in the antisense orientation at the INK4 locus). It has been shown that ANRIL regulates CDKN2A and CDKN2B expression. The two resultant proteins, CDKN2A and CDKN2B (also known as p15 INK4B and $\mathrm{p} 16^{\mathrm{INK} 4 \mathrm{~A}}$ ) are inhibitors of a cyclin-dependent kinase (CDK4 and CDK6, respectively), whereas the $\mathrm{p} 14^{\mathrm{ARF}}$ protein is expressed from an alternative frame of $C D K N 2 B$ (Figure 1). These proteins participate in the regulation of the two main tumor-suppressor pathways: RB and p53 (also known as TP53) cascades. Single-nucleotide polymorphisms (SNPs) in this region (rs10811656, rs10757278, and rs1333049) are related to the regulation of ANRIL splicing products and/or ANRIL expression. For instance, the double-carrier status on the minor alleles of rs10811656 (T) and rs10757278 (G) disrupts the STAT1-binding site and increases ANRIL expression [1,2]. 


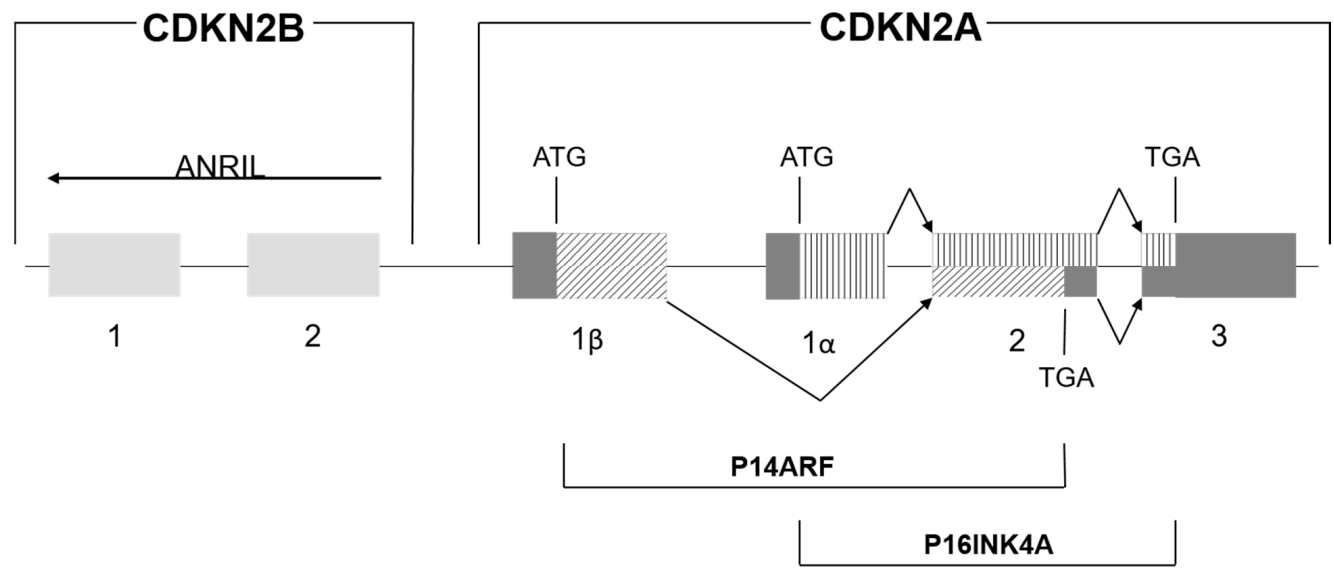

Figure 1. The $C D K N 2 B / C D K N 2 A / A N R I L$ locus in chromosomal region 9p21.

Population studies on rs1333049 have uncovered associations with CVDs and type 2 diabetes [3-9]. Patel et al. did not find a significant association between chromosome 9p21 and death/myocardial infarction as the primary outcome of CHD among patients with established CHD at baseline (odds ratio, $1.02 ; 95 \% \mathrm{CI}, 0.99-1.05)$ in a meta-analysis. In contrast to studies comparing individuals with CHD to disease-free controls, they found no clear association between genetic variation in chromosomal region 9p21 and the risk of subsequent acute CHD events when all individuals had CHD at baseline. Nonetheless, they uncovered an association with subsequent revascularization, which may support the postulated mechanism of promotion of atheroma development by chromosomal region 9p21 [10]. Data from Russian patients have confirmed the correlation of rs1333049 with myocardial infarction but not with type 2 diabetes; these studies had some limitations because they involved only small groups [11,12]. The specificity of rs1333049 as a risk factor of CVDs in various populations and ethnic groups makes this topic relevant for the populations living under various geographic/climatic conditions, including the residents of Western Siberia (Russia).

Our aim was to analyze the association of rs1333049 with clinical and biochemical parameters in the population of Western Siberia.

\section{Materials and Methods}

A cross-sectional epidemiological study on an adult population was conducted in Novosibirsk (Western Siberia, Russia). The main representative sample (9360 people, age $45-69$ years, $53.8 \pm 7.0$ [mean \pm standard error]) was compiled by means of a random number table of Novosibirsk residents analyzed in 2007-2008 during the screening within the framework of the Health, Alcohol and Psychosocial Factors In Eastern Europe (HAPIEE) study (supervised from the Wellcome Trust Foundation, Great Britain) [13]. The vast majority of the analyzed population consisted of whites $(>90 \%)$. The study protocol was approved by the Ethics Committee of the Institute of Internal and Preventive Medicine (a branch of the Institute of Cytology and Genetics, SB RAS). Written informed consent was obtained from each participant regarding study participation, the medical examination, and collection and analysis of biological materials including genetic tests.

The analyses included the recording of social-demographic data, a medical examination, a standard questionnaire about smoking, anthropometric measurements (height, body weight, and waist circumference), measurement of arterial blood pressure, and biochemical analyses of blood serum [total cholesterol (TC), high-density lipoprotein cholesterol (HDL-C), low-density lipoprotein cholesterol (LDL-C), triglycerides (TGs), and fasting blood serum glucose].

Blood collection from the median cubital vein was performed in the morning after an overnight fast for $12 \mathrm{~h}$. The blood lipid indicators (TC, TGs, HDL-C, and LDL-C) were measured by enzymatic methods with standards from Biocon Fluitest (Lichtenfels, Germany) on a Labsystem FP-901 biochemical 
analyzer (Helsinki, Finland) according to the manufacturer's instruction. The atherogenic index (AI) was calculated via the following formula: $\mathrm{AI}=(\mathrm{TC}-\mathrm{HDL}-\mathrm{C}) / \mathrm{HDL}-\mathrm{C}$.

For a molecular-genetic analysis, 2729 subjects were selected from the study population $(N=9360)$ by the random number method. DNA was isolated from blood by phenol:chloroform extraction [14].

Rs1333049 was genotyped by the commercial KASP assay [15] designed by Biolabmix, Russia and the HS-qPCR Hi-ROX (2×) (BioLabMix, Novosibirsk, Russia) on a StepOnePlus Real-Time PCR System (Thermo Fisher Scientific, Foster City, CA, USA); $1 \mu \mathrm{L}$ of assay mix, $10 \mu \mathrm{L}$ of qPCR Hi-ROX (2×) master mix, $1 \mu \mathrm{L}$ of DNA and $8 \mu \mathrm{L}$ of water with a total final volume of $20 \mu \mathrm{L}$ were used. The oligonucleotides used for rs1333049 genotyping: specific allele C $-5^{\prime}$ gagggtgaccaagttcatgcttaaccatatgatcaacagttc3'; specific allele G-5'gagggtgaccaagttcatgcttaaccatatgatcaacagttg3'; common-atttacatttccttcactactg; hydrolysis probe assays VIC aggacgctgagatgcgtcct ${ }^{*}$ gaaggtcggagtcaacggatt; hydrolysis probe assays FAM agcgatgcgttcgagcatcgct ${ }^{*}$ gagggtgaccaagttcatgct. The thermocycling programs consisted of initial denaturation at $95^{\circ} \mathrm{C}$ for $5 \mathrm{~min}$, and then 20 cycles at $95^{\circ} \mathrm{C}$ for $10 \mathrm{~s}$, annealing temperature at $54{ }^{\circ} \mathrm{C}$ for $10 \mathrm{~s}$ and $72{ }^{\circ} \mathrm{C}$ for $10 \mathrm{~s}, 30$ cycles at $95^{\circ} \mathrm{C}$ for $15 \mathrm{~s}$, annealing temperature at $52{ }^{\circ} \mathrm{C}$ for $10 \mathrm{~s}$ and extension $72{ }^{\circ} \mathrm{C}$ for $10 \mathrm{~s}$ (detection) with post PCR read $30 \mathrm{~s}$ at $60^{\circ} \mathrm{C}$. Laboratory personnel performing genotyping assays were blinded to physical and clinical examination.

For statistical analysis, the significance of differences in allele frequencies among subgroups and analysis of compliance with the Hardy-Weinberg equilibrium were carried out by the $\chi^{2}$ test. Differences in means of continuous variables among the genotypes were evaluated after adjustment for sex, age, and the body-mass index according to the GLM model of the SPSS software suite for Windows.

\section{Results}

Baseline characteristics of the subjects are presented in Table 1. The males constituted $46.5 \%$ and females $53.5 \%$. The prevalence of hypertension (>140/90 $\mathrm{mm} \mathrm{Hg}$ ) was $42.3 \%$, type 2 diabetes $7.9 \%$, dyslipidemia (TC $>200 \mathrm{mg} / \mathrm{dL}$, or $5.2 \mathrm{mmol} / \mathrm{L}$ ) $82.8 \%$ of all subjects.

Table 1. Baseline characteristics of the subjects.

\begin{tabular}{cccc}
\hline & Males & Females & Both Sexes \\
\hline Number of subjects & 1270 & 1459 & 2729 \\
Age, years & $56.7 \pm 0.2$ & $56.6 \pm 0.2$ & $56.7 \pm 0.1$ \\
TC, mg/dL & $241.5 \pm 1.4$ & $258.8 \pm 1.5$ & $250.8 \pm 1.1$ \\
HDL-C, mg/dL & $58.2 \pm 0.4$ & $61.4 \pm 0.5$ & $59.9 \pm 0.3$ \\
LDL-C, mg/dL & $119.1 \pm 1.3$ & $131.8 \pm 1.3$ & $125.9 \pm 0.9$ \\
TGs, mg/dL & $141.5 \pm 2.2$ & $144.4 \pm 2.2$ & $143.1 \pm 1.6$ \\
Index of atherogenicity & $2.9 \pm 0.04$ & $3.0 \pm 0.04$ & $2.9 \pm 0.03$ \\
Fasting glucose, mmol/L & $5.8 \pm 0.1$ & $5.8 \pm 0.1$ & $5.8 \pm 0.1$ \\
Body mass index, $\mathrm{kg} / \mathrm{m}^{2}$ & $26.7 \pm 0.1$ & $29.8 \pm 0.2$ & $28.3 \pm 0.1$ \\
Waist circumference, $\mathrm{cm}$ & $95.4 \pm 0.4$ & $92.3 \pm 0.4$ & $93.8 \pm 0.3$ \\
Systolic blood pressure, $\mathrm{mmHg}$ & $143.5 \pm 0.7$ & $143.8 \pm 0.7$ & $143.7 \pm 0.5$ \\
Diastolic blood pressure, $\mathrm{mmHg}$ & $90.4 \pm 0.4$ & $89.9 \pm 0.4$ & $89.9 \pm 0.3$ \\
Heart rate, bpm & $72.3 \pm 0.4$ & $72.0 \pm 0.3$ & $72.1 \pm 0.2$ \\
\hline
\end{tabular}

* Continuous variables are presented as mean \pm standard error. TGs, triglycerides; TC, total cholesterol; HDL-C, high-density lipoprotein cholesterol; LDL-C, low-density lipoprotein cholesterol.

The frequencies of rs1333049 alleles in the white population of Western Siberia are listed in Table 2. The associations of rs1333049 with blood lipid indicators-TC, HDL-C, LDL-C, TGs, and the atherogenic index-were studied next. Differences among the genotypes in mean levels of TC in blood were statistically significant $(p=0.004)$ only among males (Table 3$)$ : Higher mean levels of TC were noted for the genotypes involving the $\mathrm{G}$ allele. Statistically significant differences in mean TC among the genotypes were not detected among the females and in the total study population $(p>0.05)$. 
Table 2. Frequencies of the alleles and homozygous and heterozygous genotypes of rs1333049.

\begin{tabular}{|c|c|c|c|}
\hline & Males & Females & Both Sexes \\
\hline & $\begin{array}{c}\% \\
n=1270\end{array}$ & $\begin{array}{c}\% \\
n=1459\end{array}$ & $\begin{array}{c}\% \\
n=2729\end{array}$ \\
\hline \multicolumn{4}{|c|}{ Genotypes } \\
\hline $\mathrm{C} / \mathrm{C}$ & $\begin{array}{c}0.21 \\
n=271\end{array}$ & $\begin{array}{c}0.22 \\
n=322\end{array}$ & $\begin{array}{c}0.22 \\
n=593\end{array}$ \\
\hline $\mathrm{C} / \mathrm{G}$ & $\begin{array}{c}0.53 \\
n=670\end{array}$ & $\begin{array}{c}0.49 \\
n=712\end{array}$ & $\begin{array}{c}0.51 \\
n=1382\end{array}$ \\
\hline $\mathrm{G} / \mathrm{G}$ & $\begin{array}{c}0.26 \\
n=329\end{array}$ & $\begin{array}{c}0.29 \\
n=425\end{array}$ & $\begin{array}{c}0.27 \\
n=754\end{array}$ \\
\hline \multicolumn{4}{|c|}{ Alleles } \\
\hline $\mathrm{C}$ & 0.48 & 0.465 & 0.47 \\
\hline G & 0.52 & 0.535 & 0.53 \\
\hline \multicolumn{4}{|c|}{ Indicator of compliance with Hardy-Weinberg equilibrium } \\
\hline$x^{2}$ & 4.17 & 0.53 & 0.73 \\
\hline
\end{tabular}

Differences among rs1333049 genotypes in mean blood levels of LDL-C were also statistically significant $(p=0.002)$ only in males (Table 3): Higher mean levels of LDL-C in this group corresponded to genotypes $\mathrm{G} / \mathrm{G}$ and $\mathrm{C} / \mathrm{G}$. Statistically significant differences in mean LDL-C among the genotypes were not detected among the females and in the total study population $(p>0.05)$.

According to the GLM, in the analyzed groups, there were no statistically significant correlations of rs1333049 with HDL-C, TGs, the atherogenic index, blood glucose, body-mass index, systolic blood pressure, diastolic blood pressure, and heart rate.

Thus, we uncovered a statistically significant association of rs1333049 genotypes with TC and LDL-C among the white males of Western Siberia.

For 10 years (2007-2017), in the study population, investigators collected the data on new cases of myocardial infarction on the basis of the Novosibirsk City Registry of Myocardial Infarction [16]. In total, during the study period, 509 new cases of myocardial infarction were registered. In the subsample of 2729 subjects, which was genotyped for rs1333049, there were 118 new cases of myocardial infarction. In the white population of Western Siberia, we confirmed the association of rs1333049 with myocardial infarction among males (Table 4). Therefore, carriage of the $\mathrm{C}$ allele is a risk factor of myocardial infarction. 
Table 3. Associations of rs1333049 genotypes with biochemical parameters in the white population of Western Siberia.

\begin{tabular}{|c|c|c|c|c|c|c|c|c|c|c|c|}
\hline Sex & Genotype & $\mathrm{TC}, \mathrm{mg} / \mathrm{dL}$ & $\begin{array}{c}\text { HDL-C, } \\
\mathrm{mg} / \mathrm{dL}\end{array}$ & $\begin{array}{l}\text { LDL-C, } \\
\mathrm{mg} / \mathrm{dL}\end{array}$ & $\begin{array}{l}\text { TGs, } \\
\mathrm{mg} / \mathrm{dL}\end{array}$ & $\begin{array}{c}\text { Atherogenic } \\
\text { index }\end{array}$ & $\begin{array}{l}\text { Fasting } \\
\text { glucose, } \\
\text { mmol/L }\end{array}$ & $\begin{array}{c}\text { Body-mass } \\
\text { index, } \\
\mathrm{kg} / \mathrm{m}^{2}\end{array}$ & $\begin{array}{c}\text { Systolic } \\
\text { blood } \\
\text { pressure, } \\
\text { mmHg }\end{array}$ & $\begin{array}{c}\text { Diastolic } \\
\text { blood } \\
\text { pressure, } \\
\text { mmHg }\end{array}$ & $\begin{array}{c}\text { Heart rate, } \\
\text { bpm }\end{array}$ \\
\hline \multirow{3}{*}{ Male } & $\mathrm{C} / \mathrm{C}$ & $232.9 \pm 3.1$ & $58.1 \pm 0.9$ & $111.3 \pm 2.7$ & $140.0 \pm 4.8$ & $2.77 \pm 0.08$ & $5.57 \pm 0.14$ & $26.7 \pm 0.3$ & $143.5 \pm 1.4$ & $90.6 \pm 0.8$ & $71.9 \pm 0.8$ \\
\hline & $\mathrm{C} / \mathrm{G}$ & $242.5 \pm 1.9$ & $58.2 \pm 0.6$ & $119.7 \pm 1.7$ & $142.8 \pm 3.1$ & $2.90 \pm 0.05$ & $5.87 \pm 0.09$ & $26.4 \pm 0.2$ & $143.0 \pm 0.9$ & $90.1 \pm 0.5$ & $72.0 \pm 0.5$ \\
\hline & $\mathrm{G} / \mathrm{G}$ & $246.3 \pm 2.8$ & $58.4 \pm 0.9$ & $124.4 \pm 2.5$ & $140.2 \pm 4.4$ & $2.96 \pm 0.08$ & $5.77 \pm 0.12$ & $27.2 \pm 0.3$ & $144.5 \pm 1.2$ & $90.7 \pm 0.7$ & $73.3 \pm 0.7$ \\
\hline $1-12 p$ & & $0.004^{*}$ & 0.954 & 0.002 * & 0.835 & 0.229 & 0.190 & 0.061 & 0.620 & 0.785 & 0.296 \\
\hline \multirow{3}{*}{ Female } & $\mathrm{C} / \mathrm{C}$ & $265.1 \pm 3.1$ & $61.8 \pm 1.1$ & $133.5 \pm 2.8$ & $152.6 \pm 4.6$ & $3.00 \pm 0.08$ & $6.00 \pm 0.14$ & $29.9 \pm 0.3$ & $144.1 \pm 1.3$ & $90.4 \pm 0.7$ & 72.8 \\
\hline & $\mathrm{C} / \mathrm{G}$ & $257.1 \pm 2.1$ & $61.5 \pm 0.7$ & $130.9 \pm 1.9$ & $142.3 \pm 3.1$ & $2.95 \pm 0.06$ & $5.66 \pm 0.09$ & $29.7 \pm 0.2$ & $143.2 \pm 0.9$ & $89.4 \pm 0.5$ & 72.3 \\
\hline & $\mathrm{G} / \mathrm{G}$ & $257.1 \pm 2.7$ & $60.9 \pm 0.9$ & $131.9 \pm 2.4$ & $141.9 \pm 4.0$ & $2.92 \pm 0.07$ & $5.70 \pm 0.12$ & $29.7 \pm 0.3$ & $144.6 \pm 1.2$ & $90.4 \pm 0.6$ & 71.9 \\
\hline $1-12 p$ & & 0.080 & 0.787 & 0.302 & 0.133 & 0.744 & 0.116 & 0.811 & 0.615 & 0.404 & 0.605 \\
\hline \multirow{3}{*}{ Both sexes } & $\mathrm{C} / \mathrm{C}$ & $250.3 \pm 2.2$ & $60.0 \pm 0.7$ & $123.3 \pm 1.9$ & $147.0 \pm 3.4$ & $2.90 \pm 0.06$ & $5.81 \pm 0.10$ & $28.4 \pm 0.2$ & $143.9 \pm 1.0$ & $90.5 \pm 0.6$ & $72.4 \pm 0.5$ \\
\hline & $\mathrm{C} / \mathrm{G}$ & $250.4 \pm 1.5$ & $59.9 \pm 0.5$ & $125.7 \pm 1.3$ & $142.6 \pm 2.2$ & $2.93 \pm 0.04$ & $5.76 \pm 0.06$ & $28.2 \pm 0.1$ & $143.1 \pm 0.6$ & $89.8 \pm 0.4$ & $72.1 \pm 0.3$ \\
\hline & $\mathrm{G} / \mathrm{G}$ & $251.8 \pm 1.9$ & $59.7 \pm 0.6$ & $128.2 \pm 1.7$ & $140.9 \pm 2.9$ & $2.94 \pm 0.05$ & $5.73 \pm 0.09$ & $28.5 \pm 0.2$ & $144.5 \pm 0.9$ & $90.5 \pm 0.5$ & $72.6 \pm 0.5$ \\
\hline$p$ & & 0.825 & 0.937 & 0.173 & 0.386 & 0.896 & 0.835 & 0.350 & 0.397 & 0.348 & 0.770 \\
\hline
\end{tabular}

The data are presented as mean \pm standard error. ${ }^{*} \mathrm{~A}$ statistically significant difference among genotypes 
Table 4. Association of rs1333049 with myocardial infarction in the white population of Western Siberia.

\begin{tabular}{cccccccc}
\hline Sex & Genotype & \multicolumn{2}{c}{ Population } & Myocardial Infarction & OR(95\% CI) & P \\
\hline \multirow{3}{*}{ Male } & & $\mathrm{n}$ & $\%$ & $\mathrm{n}$ & $\%$ & & \\
\cline { 2 - 8 } & $\mathrm{C} / \mathrm{C}$ & 250 & 20.7 & 21 & 33.9 & $1.96(1.14-3.38)$ & $\mathbf{0 . 0 1 7}$ \\
\cline { 2 - 8 } & $\mathrm{C} / \mathrm{G}$ & 644 & 53.3 & 26 & 41.9 & $0.63(0.38-1.06)$ & 0.09 \\
\hline \multirow{3}{*}{ Female } & $\mathrm{G} / \mathrm{G}$ & 314 & 26 & 15 & 24.2 & $0.91(0.5-1.65)$ & 0.882 \\
\cline { 2 - 8 } & $\mathrm{C} / \mathrm{C}$ & 302 & 21.6 & 18 & 32.1 & $1.72(0.97-3.06)$ & 0.07 \\
\cline { 2 - 8 } & $\mathrm{C} / \mathrm{G}$ & 687 & 49 & 25 & 44.6 & $0.84(0.49-1.43)$ & 0.589 \\
\hline \multirow{3}{*}{ Both sexes } & $\mathrm{G} / \mathrm{G}$ & 412 & 29.4 & 13 & 23.2 & $0.73(0.39-1.36)$ & 0.37 \\
\cline { 2 - 8 } & $\mathrm{C} / \mathrm{C}$ & 554 & 21.2 & 39 & 33.1 & $1.83(1.23-2.72)$ & $\mathbf{0 . 0 0 4}$ \\
\cline { 2 - 7 } & $\mathrm{C} / \mathrm{G}$ & 1330 & 51 & 51 & 43.2 & $0.73(0.51-1.06)$ & 0.11 \\
\hline & $\mathrm{G} / \mathrm{G}$ & 726 & 27.8 & 28 & 23.7 & $0.81(0.52-1.24)$ & 0.4 \\
\hline
\end{tabular}

\section{Discussion}

The frequencies of rs1333049 alleles in the white population of Western Siberia were found to be consistent with those of various European populations: according to the data from gnomAD-Genomes European, $\mathrm{G}=0.528, \mathrm{C}=0.472$ (http://www.ncbi.nlm.nih.gov).

For SNP rs1333049 in the total study population and among females, the frequencies of genotypes were compliant with the Hardy-Weinberg equilibrium. In males, the observed distribution of genotype frequencies did not match the theoretically expected one because of lower frequencies of genotypes G/G (homozygous) and C/G (heterozygous). The observed noncompliance with the Hardy-Weinberg equilibrium among the rs1333049 genotype frequencies in males most likely indicates selection for this SNP.

Carriage of the $C$ allele is a risk factor of myocardial infarction in the white population of Western Siberia. Such an association has been found in various ethnic groups elsewhere. The minor allele (risk allele) of rs1333049 (C) is widespread across the globe. This allele raises the risk of ischemic heart disease by $15-20 \%$ in the heterozygous state and by $30-40 \%$ in the homozygous state [17-19]. According to the literature, chromosomal locus 9.21, where rs1333049 is located, may be involved in the signaling pathway associated with inflammation in the arterial wall [20].

Individual risk of CVDs depends on both genetic factors and lifestyle factors. This study presents the results of our analysis of a Russian population for the association of SNP rs1333049 with clinical and biochemical parameters. Changes in DNA sequence are an independent risk factor of myocardial infarction, in agreement with the findings of other authors [21-32]. The risk of an unfavorable outcome depends on the presence of a certain allele or genotype.

Our study revealed an association of the G allele of rs1333049 with TC and LDL-C levels among males. These data contradict some other studies [10,11,33], for example, Ellis et al. have demonstrated a correlation of the C/C genotype with higher TG and TC levels in blood [26]. The study by Ellis et al. was performed on patients with ischemic heart disease (New Zealand), whereas our study deals with the general population. Perhaps the observed association may be explained by clinical and group features of the populations being analyzed. In most studies on groups of patients, an association of rs1333049 with lipid metabolism parameters has not been detected [34].

Our study confirmed the association of rs1333049 with myocardial infarction in the general population; this finding is consistent with the results of studies on some groups of patients in Russia [11,12,35] and abroad [35-38].

According to the GLM, in the analyzed groups, there were no statistically significant correlations of rs1333049 with blood glucose levels. In other studies, there have been no statistically significant 
correlations of rs1333049 with type 2 diabetes in Russia [11,12]. Here, in 242 patients out of 2729, the diagnosis was type 2 diabetes. According to the GLM, in the analyzed groups, there were no statistically significant correlations of rs1333049 with type 2 diabetes in the white population of Western Siberia.

Our study has some limitations. We analyzed only rs1333049 (which is located in the 9p21.3 region) and traditional CVD risk factors; therefore, we could not rule out the influence of other factors that may affect the results of observational studies.

The research into genetic risk factors of CVDs is important not only for the analysis of disease outcomes but also for preventive measures, considering that genetic variants can be detected before the first clinical manifestations of a CVD. Accordingly, patients at a high risk of CVD (in terms of genetic factors) may have additional motivation to lead a healthy lifestyle [21]. Furthermore, information about genetic risk factors of a disease may be employed to improve the clinical management of the patients.

Ethics approval and consent to participate: The study protocol was approved by the Ethics Committee of the Institute of Internal and Preventive Medicine (a branch of the Institute of Cytology and Genetics, SB RAS, Novosibirsk, Russia; №7, 22.06.2008.).

Author Contributions: E.S.: analysis and interpretation of the data in the genetic part of the work, drafting of the manuscript, and participation in the discussion; P.O.: the genetic part of the work; S.S.: the genetic part of the work; D.I.: data analysis and participation in the discussion; S.M.: analysis of the clinical data; V.G.: analysis of the data from the Novosibirsk City Registry of Myocardial Infarction; Y.R.: analysis of the biochemical data; M.V.: study conception and design and critical revision of the manuscript.

Funding: This study was conducted within the framework of Russian Fund for Basic Research project No. 17-06-01045 and as part of the budget topic in state assignment No. 0324-2018-0001.

Acknowledgments: The English language was corrected and certified by shevchuk-editing.com. The authors are grateful to Vladimir N. Maksimov (the Laboratory of Molecular Genetic Investigations of Therapeutic Diseases, the Institute of Internal and Preventive Medicine-a branch of the Institute of Cytology and Genetics, SB RAS) for technical assistance. The authors thank the patients for participation in this study.

Conflicts of Interest: The authors declare that they have no conflicts of interest associated with publication of this article.

$\begin{array}{ll}\text { Abbreviations } \\ \text { CHD } & \text { coronary heart disease } \\ \text { CVD } & \text { cardiovascular disease } \\ \text { HDL-C } & \text { high-density lipoprotein cholesterol } \\ \text { LDL-C } & \text { low-density lipoprotein cholesterol } \\ \text { PCR } & \text { polymerase chain reaction } \\ \text { SNV } & \text { single-nucleotide variant } \\ \text { TC } & \text { total cholesterol } \\ \text { TGs } & \text { triglycerides }\end{array}$

\section{References}

1. Chi, J.S.; Li, J.Z.; Jia, J.J.; Zhang, T.; Liu, X.M.; Yi, L. Long Non-coding RNA ANRIL in Gene Regulation and Its Duality in Atherosclerosis. J. Huazhong Univ. Sci. Technolog. Med. Sci. 2017, 37, 816-822. [CrossRef] [PubMed]

2. Mercer, T.R.; Dinger, M.E.; Mattick, J.S. Long non-coding RNAs: Insights into functions. Nat. Rev. Genet. 2009, 10, 155-159. [CrossRef] [PubMed]

3. Chen, G.; Fu, X.; Liu, G.; Bai, X. Genetic Variant rs10757278 on Chromosome 9p21 Contributes to Myocardial Infarction Susceptibility. Int. J. Mol. Sci. 2015, 16, 11678-11688. [CrossRef] [PubMed]

4. Karvanen, J.; Silander, K.; Kee, F.; Tiret, L.; Salomaa, V.; Kuulasmaa, K.; Wiklund, P.G.; Virtamo, J.; Saarela, O.; Perret, C.; et al. The impact of newly identified loci on coronary heart disease, stroke and total mortality in the MORGAM prospective cohorts. Genet. Epidemiol. 2009, 33, 237-246. [CrossRef] [PubMed]

5. Fan, M.; Dandona, S.; McPherson, R.; Allayee, H.; Hazen, S.L.; Wells, G.A.; Roberts, R.; Stewart, A.F.R. Two chromosome 9p21 haplotype blocks distinguish between coronary artery disease and myocardial infarction risk. Circ. Cardiovasc. Genet. 2013, 6, 372-380. [CrossRef] [PubMed] 
6. Kashyap, S.; Kumar, S.; Agarwal, V.; Misra, D.P.; Rai, M.K.; Kapoor, A. The association of polymorphic variants, rs2267788, rs1333049 and rs2383207 with coronary artery disease, its severity and presentation in North Indian population. Gene 2018, 648, 89-96. [CrossRef]

7. Rivera, N.V.; Carreras-Torres, R.; Roncarati, R.; Viviani-Anselmi, C.; De Micco, F.; Mezzelani, A.; Koch, W.; Hoppmann, P.; Kastrati, A.; Stewart, A.F.R.; et al. Assessment of the 9p21.3 locus in severity of coronary artery disease in the presence and absence of type 2 diabetes. BMC Med. Genet. 2013, 14, 11. [CrossRef]

8. Abid, K.; Mili, D.; Kenani, A. Polymorphism on Chromosome 9p21.3 Is Associated with Severity and Early-Onset CAD in Type 2 Diabetic Tunisian Population. Dis. Markers 2015, 2015, 792679. [CrossRef]

9. Wu, Z.; Sheng, H.; Su, X.; Gao, X.; Lu, L.; Jin, W. Mediating Effect of Diabetes Mellitus on the Association Between Chromosome 9p21.3 Locus and Myocardial Infarction Risk: A Case-Control Study in Shanghai, China. Front Endocrinol. (Lausanne) 2018, 9, 362. [CrossRef]

10. Patel, R.S.; Schmidt, A.F.; Tragante, V.; McCubrey, R.O.; Holmes, M.V.; Howe, L.J.; Direk, K.; Åkerblom, A.; Leander, K.; Virani, S.S.; et al. Association of Chromosome 9p21 With Subsequent Coronary Heart Disease Events. Circ. Genom. Precis Med. 2019, 12, e002471. [CrossRef]

11. Maksimov, V.N.; Orlov, P.S.; Ivanova, A.A.; Lozhkina, N.G.; Kuimov, A.D.; Savchenko, S.V.; Novoselov, V.P.; Voevoda, M.I.; Malyutina, S.K. Complex evaluation of the significance of populational genetic markers associated with myocardial infarction and risk factors. Rus. J. Cardiol. 2017, 150, 33-41. [CrossRef]

12. Goncharova, I.A.; Makeeva, O.A.; Markov, A.V.; Tarasenko, N.V.; Sleptsov, A.A.; Puzyrev, V.P. Genes for Fibrogenesis in the Determination of Susceptibility to Myocardial Infarction. Mol. Biol. [Mosk] 2016, 50, 94-105. [CrossRef]

13. Peasey, A.; Bobak, M.; Kubinova, R.; Malyutina, S.K.; Pajak, A.; Tamosiunas, A.; Pikhart, H.; Nicholson, A.; Marmot, M. Determinants of cardiovascular disease and other non-communicable diseases in Central and Eastern Europe: Rationale and Design of the HAPIEE study. BMC Public Health 2006, 6, 255. [CrossRef] [PubMed]

14. Sambrook, J.; Russell, D.W. Purification of nucleic acids by extraction with phenol:chloroform. CSH Protoc. 2006, 1. [CrossRef] [PubMed]

15. He, C.; Holme, J.; Anthony, J. SNP Genotyping: The KASP Assay. In Crop Breeding; Delphine, F., Whitford, R., Eds.; Springer: New York, NY, USA, 2014; pp. 75-86.

16. Gafarov, V.; Gafarova, A. Who programs: "register acute myocardial infarction”, “Monica”—dynamics acute cardiovascular accident at years 1977-2009 in general population aged 25-64 years in Russia. Rus. J. Cardiol. 2016, 132, 129-134. [CrossRef]

17. Helgadottir, A.; Thorleifsson, G.; Manolescu, A.; Gretarsdottir, S.; Blondal, T.; Jonasdottir, A.; Jonasdottir, A.; Sigurdsson, A.; Baker, A.; Palsson, A.; et al. A common variant on chromosome 9p21 affects the risk of myocardial infarction. Science 2007, 316, 1491-1493. [CrossRef] [PubMed]

18. McPherson, R.; Pertsemlidis, A.; Kavaslar, N.; Stewart, A.; Roberts, R.; Cox, D.R.; Hinds, D.A.; Pennacchio, L.A.; Tybjaerg-Hansen, A.; Folsom, A.R.; et al. A common allele on chromosome 9 associated with coronary heart disease. Science 2007, 316, 1488-1491. [CrossRef]

19. Krimpenfort, P.; Ijpenberg, A.; Song, J.Y.; van der Valk, M.; Nawijn, M.; Zevenhoven, J.; Berns, A. p15Ink4b is a critical tumour suppressor in the absence of p16Ink4a. Nature 2007, 448, 943-946. [CrossRef]

20. Guo, Y.; Garcia-Barrio, M. Experimental Biology for the Identification of Causal Pathways in Atherosclerosis. Cardiovasc. Drugs Ther. 2016, 30,1-11. [CrossRef]

21. Khera, A.; Emdin, C.; Drake, I.; Natarajan, P.; Bick, A.G.; Cook, N.R.; Chasman, D.I.; Baber, U.; Mehran, R.; Rader, D.J.; et al. Genetic Risk, Adherence to a Healthy Lifestyle, and Coronary Disease. N. Engl. J. Med. 2016. [CrossRef]

22. Stenlund, H.; Lönnberg, G.; Jenkins, P.; Norberg, M.; Persson, M.; Messner, T.; Boman, K.; Pearson, T.; Wall, S.; Nyström, L.; et al. Fewer deaths from cardiovascular disease than expected from the Systematic Coronary Risk Evaluation chart in a Swedish population. Eur. J. Cardiovasc. Prev. Rehabil. 2009, 16, 321-324. [CrossRef]

23. Lloyd-Jones, D.M.; Wilson, P.W.; Larson, M.G.; Beiser, A.; Leip, E.P.; D’Agostino, R.B.; Levy, D. Framingham risk score and prediction of lifetime risk for coronary heart disease. Am. J. Cardiol. 2004, 94, 20-24. [CrossRef]

24. Ripatti, S.; Tikkanen, E.; Orho-Melander, M.; Havulinna, A.S.; Silander, K.; Sharma, A.; Guiducci, C.; Perola, M.; Jula, A.; Sinisalo, J.; et al. A multilocus genetic risk score for coronary heart disease: Case-control and prospective cohort analyses. Lancet 2010, 376, 1393-1400. [CrossRef] 
25. Thanassoulis, G.; Peloso, G.M.; Pencina, M.J.; Hoffmann, U.; Fox, C.S.; Cupples, L.A.; Levy, D.; D'Agostino, R.B.; Hwang, S.-J.; O'Donnell, C.J. A genetic risk score is associated with incident cardiovascular disease and coronary artery calcium: The Framingham Heart Study. Circ. Cardiovasc. Genet. 2012, 5, 113-121. [CrossRef]

26. Brautbar, A.; Pompeii, L.A.; Dehghan, A.; Ngwa, J.S.; Nambi, V.; Virani, S.S.; Rivadeneira, F.; Uitterlinden, A.G.; Hofman, A.; Witteman, J.C.; et al. A genetic risk score based on direct associations with coronary heart disease improves coronary heart disease risk prediction in the Atherosclerosis Risk in Communities (ARIC), but not in the Rotterdam and Framingham Offspring, Studies. Atherosclerosis 2012, 223, 421-426. [CrossRef]

27. Mega, J.L.; Stitziel, N.O.; Smith, J.G.; Chasman, D.I.; Caulfield, M.J.; Devlin, J.J.; Nordio, F.; Hyde, C.L.; Cannon, C.P.; Sacks, F.M.; et al. Genetic risk, coronary heart disease events, and the clinical benefit of statin therapy: An analysis of primary and secondary prevention trials. Lancet 2015, 385, 2264-2271. [CrossRef]

28. Tada, H.; Melander, O.; Louie, J.Z.; Catanese, J.J.; Rowland, C.M.; Devlin, J.J.; Kathiresan, S.; Shiffman, D. Risk prediction by genetic risk scores for coronary heart disease is independent of self-reported family history. Eur. Heart J. 2016, 37, 561-567. [CrossRef]

29. Westermair, A.L.; Munz, M.; Schaich, A.; Nitsche, S.; Willenborg, B.; Venegas, L.M.; Willenborg, C.; Schunkert, H.; Schweiger, U.; Erdmann, J. Association of Genetic Variation at AQP4 Locus with Vascular Depression. Biomolecules 2018, 8, 164. [CrossRef]

30. Severino, P.; D'Amato, A.; Netti, L.; Pucci, M.; De Marchis, M.; Palmirotta, R.; Volterrani, M.; Mancone, M.; Fedele, F. Diabetes Mellitus and Ischemic Heart Disease: The Role of Ion Channels. Int. J. Mol. Sci. 2018, 19, 802. [CrossRef]

31. Foroughmand, A.M.; Nikkhah, E.; Galehdari, H.; Jadbabaee, M.H. Association study between coronary artery disease and rs1333049 and rs10757274 polymorphisms at 9p21 locus in south-west Iran. Cell J. 2015, 17, 89-98.

32. Severino, P.; D’Amato, A.; Netti, L.; Pucci, M.; Infusino, F.; Maestrini, V.; Mancone, M.; Fedele, F. Myocardial Ischemia and Diabetes Mellitus: Role of Oxidative Stress in the Connection between Cardiac Metabolism and Coronary Blood Flow. J. Diabetes Res. 2019, 2019, 9489826. [CrossRef]

33. Ellis, K.L.; Pilbrow, A.P.; Frampton, C.M.; Doughty, R.N.; Whalley, G.A.; Ellis, C.J.; Palmer, B.R.; Skelton, L.; Yandle, T.G.; Palmer, S.C.; et al. A Common Variant at Chromosome 9P21.3 Is Associated with Age of Onset of Coronary Disease but Not Subsequent Mortality. Circ. Cardiovasc. Genet. 2010, 3, 286-293. [CrossRef]

34. Pignataro, P.; Pezone, L.; Di Gioia, J.; Franco, D.; Iaccarino, G.; Iolascon, A.; Ciccarelli, M.; Capasso, M. Association Study Between Coronary Artery Disease and rs1333049 Polymorphism at 9p21.3 Locus in Italian Population. J. Cardiovasc. Trans. Res. 2017, 10, 455-458. [CrossRef]

35. Osmak, G.; Titov, B.; Matveeva, N.A.; Bashinskaya, V.V.; Shakhnovich, R.M.; Sukhinina, T.S.; Kukava, N.G.; Ruda, M.Y.; Favorova, O.O. Impact of 9p21.3 region and atherosclerosis-related genes' variants on longterm recurrent hard cardiac events after a myocardial infarction. Gene 2018, 647, 283-288. [CrossRef]

36. Yang, J.; Gu, L.; Guo, X.; Huang, J.; Chen, Z.; Huang, G.; Kang, Y.; Zhang, X.; Long, J.; Su, L. LncRNA ANRIL Expression and ANRIL Gene Polymorphisms Contribute to the Risk of Ischemic Stroke in the Chinese Han Population. Cell. Mol. Neurobiol. 2018, 38, 1253-1269. [CrossRef]

37. Bressler, J.; Folsom, A.R.; Couper, D.J.; Volcik, K.A.; Boerwinkle, E. Genetic variants identified in a european genome-wide association study that were found to predict incident coronary heart disease in the atherosclerosis risk in communities study. Am. J. Epidemiol. 2010, 171, 14-23. [CrossRef]

38. Jansen, M.D.; Knudsen, G.P.; Myhre, R.; Høiseth, G.; Mørland, J.; Næss, Ø.; Tambs, K.; Magnus, P. Genetic variants in loci 1p13 and 9p21 and fatal coronary heart disease in a Norwegian case-cohort study. Mol. Biol Rep. 2014, 41, 2733-2743. [CrossRef]

Sample Availability: The datasets of this study are available from the corresponding author upon reasonable request.

(C) 2019 by the authors. Licensee MDPI, Basel, Switzerland. This article is an open access article distributed under the terms and conditions of the Creative Commons Attribution (CC BY) license (http://creativecommons.org/licenses/by/4.0/). 